\title{
Zoophobia and Gender - A Case Study
}

Sankara Pitchaiah Podila*, Nazia Sultana

Department of Geology, Acharya Nagarjuna University, Andhra Pradesh, India

*Corresponding author email: lifeskillssankar@gmail.com

\begin{abstract}
Zoophobia is one type of specific phobia. It is a fear of animals. The present study was carried out to know the degree of Zoophobia among $8^{\text {th }}$ to $10^{\text {th }}$ Government high school students. The response was taken from 2743 students (Male: 1589 Female: 1154). The study found that $20.57 \%$ of male students expressed the phobia and it is $32.84 \%$ in the case of female. Comparatively, high percentage of female students have Zoophobia than male. Some of the useful treatment methods are Homeopathy, Exposure based therapy, Cognitive therapy and Relaxation techniques.
\end{abstract}

Keywords: Zoophobia, Therapy, Male And Female, High School Students

\section{INTRODUCTION}

Zoophobia or animal phobia is a class of specific phobias of a particular animal (Fodor and Gaynor, 2004) or an irrational fear or even simply dislike of any non-human animals. Examples of specific zoophobias would be entomophobia, such as that of bees (apiphobia), fear of spiders (arachnophobia), birds (ornithophobia) and snakes (ophidiophobia) (https://en.wiki-pedia.org).

Various studies were carried out on specific phobias (Ollendick et al., 2010; https://www.very wellmind.com/; Curtis et al., 1998; de Oliveira-Souza 2018; Naveed et al., 2015; Carleton 2016; Garcia 2017 Pull 2008 and Singh and Singh 2016.

The present study was carried out to know the degree of Zoophobia among male and female students of $8^{\text {th }}$ to $10^{\text {th }}$ class Government school students.

\section{Symptoms}

Zoophobia is exposed to or even things about the animal dreaded, they will go through physical and emotional symptoms of extreme anxiety reaction, like: excessive sweating, trouble controlling muscles, dizziness, fainting, elevated heart rate, rapid and shallow breathing, etc. (Suarez et al., 2017)

\section{METHODOLOGY}

A total of 2743 students, studying $8^{\text {th }}$ to $10^{\text {th }}$ in Government high schools was participated, out of them 1589 are male and 1154 were female. The details are shown in Tables 1 and 2. Students were assembled in a classroom of the respective schools and asked them to give their response to a single question. "Do you have a fear of Animals ?" The purpose of the study and the details regarding the phobia were explained in their mother tongue. The data were analyzed using statistical analysis. Percent variation was observed and presented under results and discussion. 
TABLE 1 SCHOOL WISE, CLASS WISE AND GENDER WISE STUDENT'S STRENGTH

\begin{tabular}{|l|c|c|c|c|c|c|c|c|c|}
\hline \multicolumn{1}{|c|}{ Classes $\rightarrow$} & \multicolumn{3}{|c|}{ 8th } & \multicolumn{3}{c|}{ 9th } & \multicolumn{3}{c|}{ 10th } \\
\hline \multicolumn{1}{|c}{ Schools } & Male & Female & Total & Male & Female & Total & Male & Female & Total \\
\hline Ponnekallu & 52 & 40 & 92 & 36 & 42 & 78 & 49 & 40 & 89 \\
\hline Takkellapadu & 27 & 37 & 64 & 25 & 22 & 47 & 24 & 23 & 47 \\
\hline Venigalla & 33 & 52 & 85 & 31 & 37 & 68 & 48 & 55 & 103 \\
\hline Koppuravuru & 40 & 36 & 76 & 39 & 28 & 67 & 30 & 23 & 53 \\
\hline SK & 104 & 75 & 179 & 106 & 54 & 160 & 118 & 70 & 188 \\
\hline SJRR & 80 & 53 & 133 & 78 & 47 & 125 & 48 & 45 & 93 \\
\hline SKS & 55 & 45 & 100 & 46 & 48 & 94 & 67 & 51 & 118 \\
\hline P & 75 & 17 & 92 & 62 & 21 & 83 & 57 & 20 & 77 \\
\hline KSR & 26 & 26 & 52 & 62 & 17 & 79 & 30 & 26 & 56 \\
\hline SCMP & 54 & 39 & 93 & 40 & 36 & 76 & 47 & 29 & 76 \\
\hline Total & $\mathbf{5 4 6}$ & $\mathbf{4 2 0}$ & $\mathbf{9 6 6}$ & $\mathbf{5 2 5}$ & $\mathbf{3 5 2}$ & $\mathbf{8 7 7}$ & $\mathbf{5 1 8}$ & $\mathbf{3 8 2}$ & $\mathbf{9 0 0}$ \\
\hline
\end{tabular}

TABLE 2 SCHOOL WISE AND GENDER WISE STUDENTS WITH ZOOPHOBIA

\begin{tabular}{|l|c|c|c|c|c|c|}
\hline \multicolumn{1}{|c|}{ Classes $\rightarrow$} & \multicolumn{2}{c|}{ 8th } & \multicolumn{2}{c|}{ 9th } & \multicolumn{2}{c|}{ 10th } \\
\hline \multicolumn{1}{|c|}{ Schools } & Male & Female & Male & Female & Male & Female \\
\hline Ponnekallu & 14 & 8 & 2 & 8 & 16 & 21 \\
\hline Takkellapadu & 6 & 20 & 9 & 14 & 14 & 21 \\
\hline Venigalla & 7 & 13 & 6 & 14 & 5 & 13 \\
\hline Koppuravuru & 6 & 5 & 8 & 2 & 2 & 11 \\
\hline SK & 14 & 13 & 10 & 11 & 15 & 28 \\
\hline SJRR & 14 & 13 & 19 & 13 & 15 & 9 \\
\hline SKS & 11 & 23 & 12 & 15 & 10 & 10 \\
\hline P & 15 & 6 & 7 & 12 & 23 & 14 \\
\hline KSR & 6 & 7 & 14 & 5 & 3 & 4 \\
\hline SCMP & 18 & 17 & 10 & 13 & 16 & 16 \\
\hline Total & 111 & 125 & 97 & 107 & 119 & 147 \\
\hline
\end{tabular}

\section{RESULTS AND DISCUSSION}

\section{Male}

A percent variation of the male and female students, $8^{\text {th }}$ class those suffering from Zoophobia was shown in table 3 Highest percent of SCMP school students (19.35) and figures 1 and 2 . were marked the Zoophobia (Figure 1A), followed by P (16.30\%), Ponnekallu (15.22\%). The lowest percent was noticed with SK $(7.82 \%)$. 
TABLE 3 PERCENTAGE OF MALE AND FEMALE STUDENTS WITH ZOOPHOBIA

\begin{tabular}{|l|c|c|c|c|c|c|}
\hline \multicolumn{1}{|c|}{ Classes $\rightarrow$} & \multicolumn{2}{|c|}{ 8th } & \multicolumn{2}{c|}{ 9th } & \multicolumn{2}{c|}{ 10th } \\
\hline Schools & Male & Female & Male & Female & Male & Female \\
\hline Ponnekallu & 15.22 & 8.70 & 2.56 & 10.26 & 17.98 & 23.60 \\
\hline Takkellapadu & 9.38 & 31.25 & 19.15 & 29.79 & 29.79 & 44.68 \\
\hline Venigalla & 8.24 & 15.29 & 8.82 & 20.59 & 4.85 & 12.62 \\
\hline Koppuravuru & 7.89 & 6.58 & 11.94 & 2.99 & 3.77 & 20.75 \\
\hline SK & 7.82 & 7.26 & 6.25 & 6.88 & 7.98 & 14.89 \\
\hline SJRR & 10.53 & 9.77 & 15.20 & 10.40 & 16.13 & 9.68 \\
\hline SKS & 11.00 & 23.00 & 12.77 & 15.96 & 8.47 & 8.47 \\
\hline P & 16.30 & 6.52 & 8.43 & 14.46 & 29.87 & 18.18 \\
\hline KSR & 11.54 & 13.46 & 17.72 & 6.33 & 5.36 & 7.14 \\
\hline SCMP & 19.35 & 18.28 & 13.16 & 17.11 & 21.05 & 21.05 \\
\hline
\end{tabular}

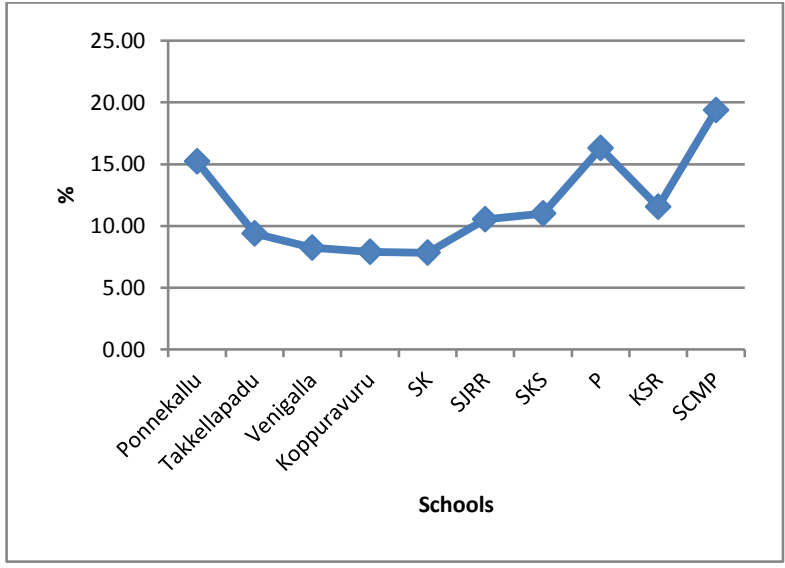

Figure 1A - $8^{\text {th }}$ Male Students with Zoophobia

$9^{\text {th }}$ Class

$19.15 \%$ of Takkellapadu school students had expressed the Zoophobia (Figure 1B), followed by KSR school students (17.72\%) and SJRR (15.20\%). Comparatively, the problem is low in Ponnekallu (2.56\%).

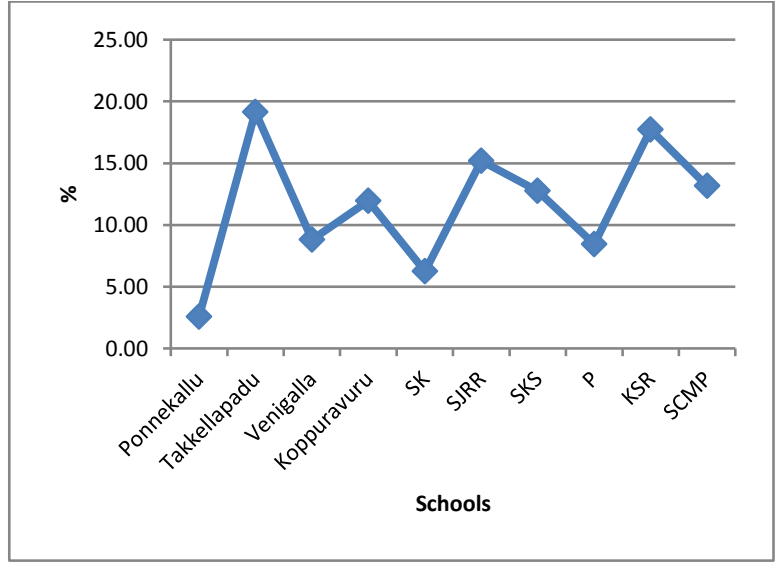

Figure 1B -9 $9^{\text {th }}$ Male Students with Zoophobia

$10^{\text {th }}$ Class

Highest percent of P students (29.87) were marked the Zoophobia (Figure 1C), followed by Takkellapadu (29.79\%) and SCMP (21.05\%). The lowest percentage was noticed with Koppuravuru (3.77). 


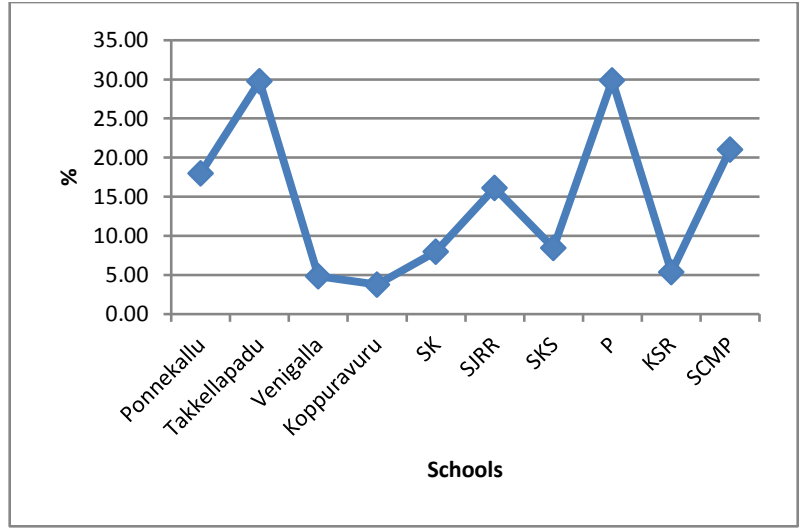

Figure 1C - $10^{\text {th }}$ Male Students with Zoophobia

\section{Female}

\section{$8^{\text {th }}$ Class}

$31.25 \%$ of Takkellapadu students were pointed Zoophobia (Figure 2A), followed by SKS (23.00\%) and SCMP (18.28\%). The lowest percent was observed with $\mathrm{P}(6.52 \%)$.

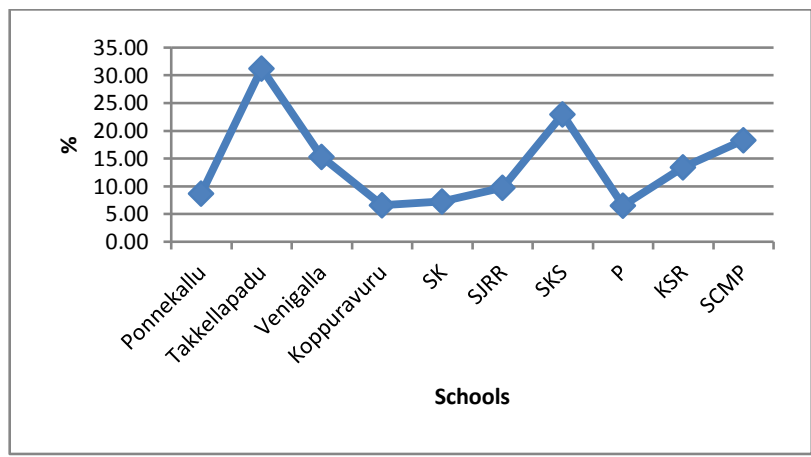

Figure $2 \mathrm{~A}-8^{\text {th }}$ Female Students with Zoophobia

$9^{\text {th }}$ Class

Highest percent of Takkellapadu (29.79) school students had Zoophobia (Figure 2B), followed by Venigalla (20.59\%) and SCMP (17.11\%). The lowest

\section{Comparative study}

\section{Male ( $8^{\text {th }}$ to $10^{\text {th }}$ )}

Comparison of Zoophobia among $8^{\text {th }}$ to $10^{\text {th }}$ class male students was shown in table 3 and figure 3). Among the male students, high percent of $\mathrm{P}, 10^{\text {th }}$ students (29.87\%) had Zoophobia followed by Takkellapadu (29.79\%), and SCMP (21.05\%). The percent was observed in Koppuravuru students (2.99\%).

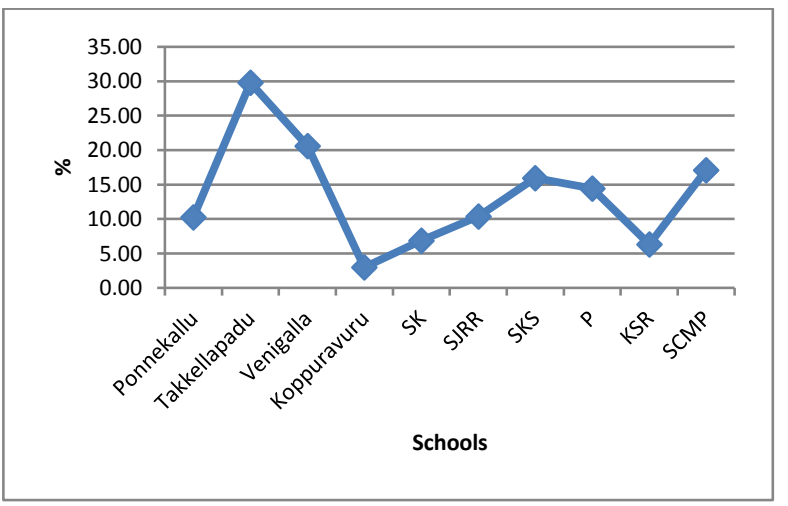

Figure 2B $-9^{\text {th }}$ Female Students with Zoophobia

$10^{\text {th }}$ Class

$44.68 \%$ of Takkellapadu students were suffering from Zoophobia (Figure 2C), followed by Ponnekallu (23.60\%) and SCMP (21.05\%). The lowest percent was observed with KSR (7.14).

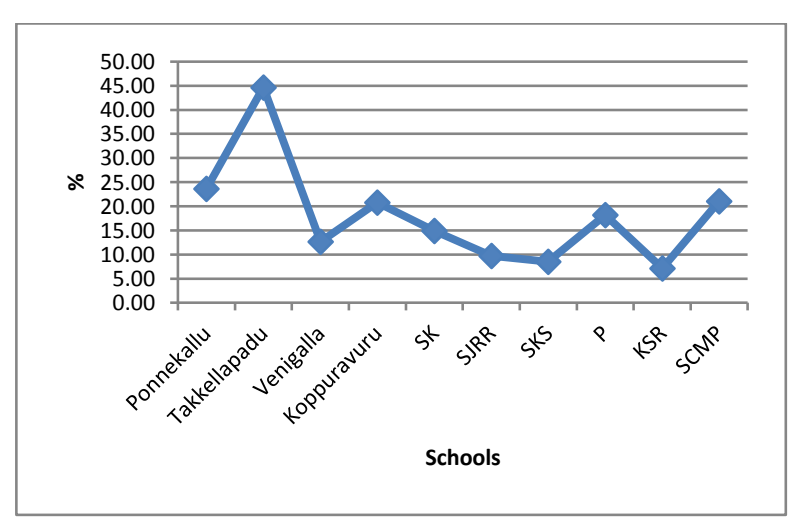

Figure 2C - 10 ${ }^{\text {th }}$ Female Students with Zoophobia

lowest percent was observed with Ponnekallu, 9th class students $(2.56 \%)$. 


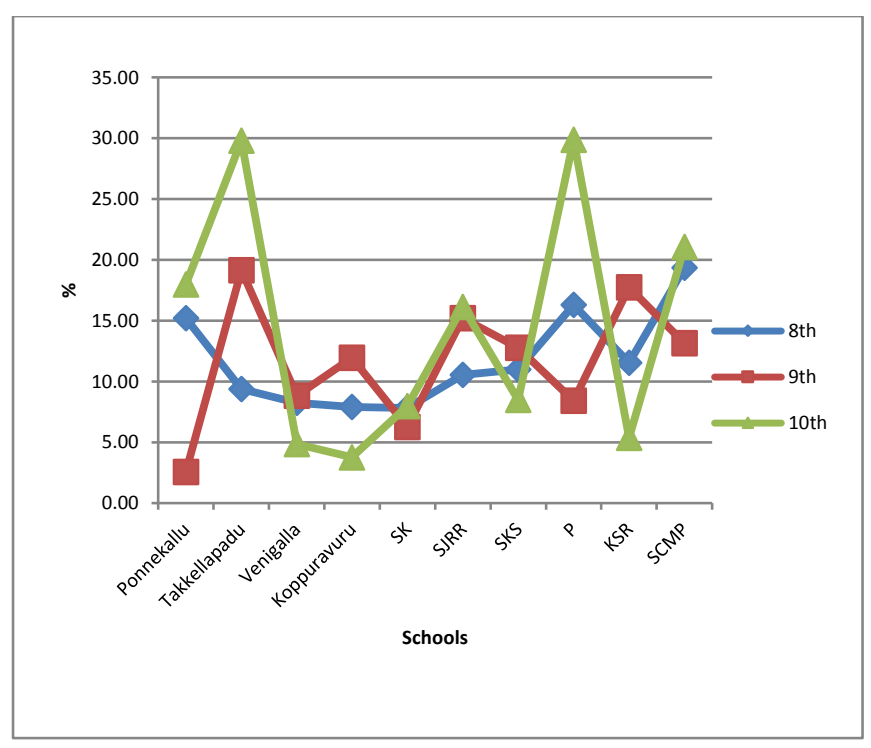

Figure $3.8^{\text {th }}$ to $10^{\text {th }}$ class male students with

\section{Zoophobia}

\section{Female ( $8^{\text {th }}$ to $\left.10^{\text {th }}\right)$}

In the case of female students, high percent of Takkellapadu 10 $10^{\text {th }}$ students (44.68) had an Zoophobia (Table 3 and Figure 4), followed by Takkellapadu of $8^{\text {th }}$ students $(31.25 \%), 9^{\text {th }}$ students $(29.79 \%)$. The lowest percent was observed with Koppuravuru $9^{\text {th }}$ class students (2.99\%).

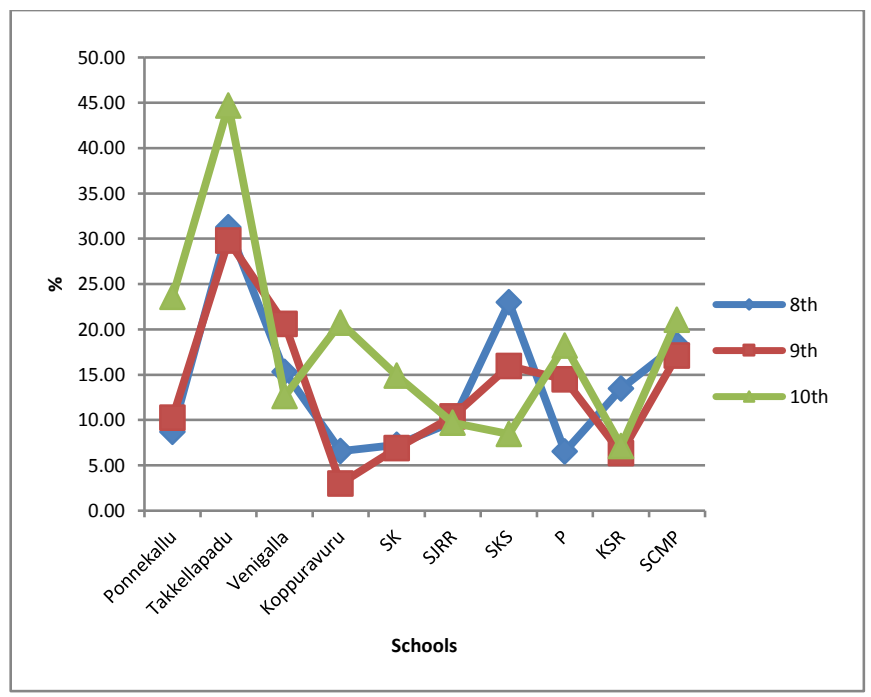

Figure $4.8^{\text {th }}$ to $10^{\text {th }}$ class female students with Zoophobia

\section{Comparison of Zoophobia between Male and Female}

Comparison of Zoophobia among $8^{\text {th }}$ to $10^{\text {th }}$ class male and female students was shown in table 4 and figure 5). Highest percent of Takkellapadu (18.35) male had expressed Zoophobia, followed by SCMP (17.96\%) and P (17.86\%). The lowest percent was observed with Venigalla (7.03\%). In the case of female students, highest percent of Takkellapadu (34.81) had chosen, followed by SCMP (18.78\%) and Venigalla (15.63\%). The lowest percentage was observed with KSR (8.56\%).

The study found that the phobia was high in female students than male.

TABLE 4 COMPARISON OF ZOOPHOBIA BETWEEN MALE AND FEMALE STUDENTS (\%)

\begin{tabular}{|l|l|l|}
\hline Schools & Male & Female \\
\hline Ponnekallu & 12.36 & 14.29 \\
\hline Takkellapadu & 18.35 & 34.81 \\
\hline Venigalla & 7.03 & 15.63 \\
\hline Koppuravuru & 8.16 & 9.18 \\
\hline SK & 7.40 & 9.87 \\
\hline SJRR & 13.68 & 9.97 \\
\hline SKS & 10.58 & 15.38 \\
\hline P & 17.86 & 12.70 \\
\hline KSR & 12.30 & 8.56 \\
\hline SCMP & 17.96 & 18.78 \\
\hline
\end{tabular}

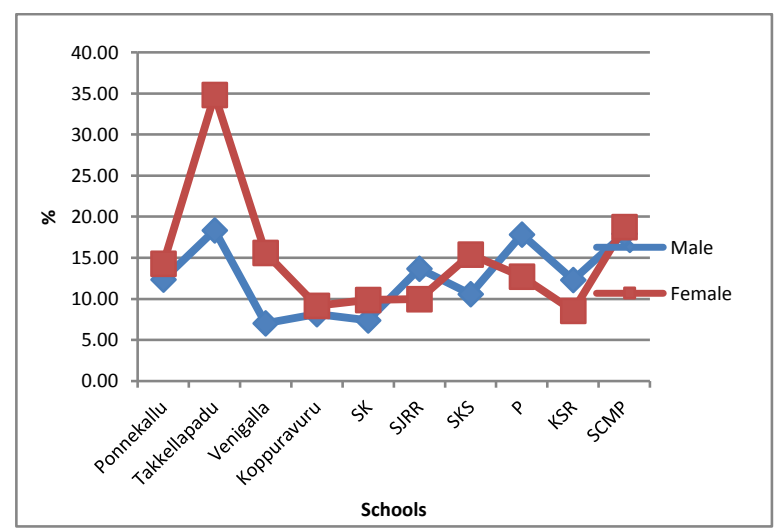

Figure 5. Zoophobia among $8^{\text {th }}$ to $10^{\text {th }}$ class male and female students

Katkin and Hoffman (1976) hypothesized that, because of differential social learning, females would report fear of spiders more frequently than males 
would but that males selected for equal self-report of fear would show greater autonomic responsivity than females to slides of spiders. Results confirm the hypothesis that more women would report fear than men but failed to confirm the hypothesis that there would be differential autonomic responding.

Cornelius and Averill (1983) studied on Sex differences in fear of spiders and concluded that the presence of a live spider, women reported more subjective unpleasantness and tension and had higher heart rates than did men.

\section{Treatment Methods}

The specific phobias, including animal phobias, are easier to treat. They do not represent a fear of an internal feeling-which can go anywhere that the affected person goes-but rather fear of a very particular thing (https://www.psychologytoday.com).

There are certain therapies by which this phobia is treatable. The main treatment of choice for specific phobias is Cognitive-behavioral (CBT). Behavioral techniques by which survivor is exposed to feared situations (gradually or rapidly) are frequently used. In addition, the patient is taught ways of stopping the panic reaction and regaining emotional control (Abbas and Kiran, 2015).

Suarez et al., (2017) were working with a project to provide a reasonable alternative for treating various types of Zoophobias, using virtual reality, beginning with the fear of cockroaches. To achieve said objective, a virtual world is developed by them using Unity, and Sweet Home 3D, and is implemented into an Oculus Rift virtual reality glasses. Patients will be transported to a house-like environment with the Oculus Rift, and gradually exposed to the cockroaches, while progressively approaching them with no real risk or further traumatization. This will be made to feel as realistic as possible to help the patient feel more at home, while helping them adjust to their fears in places where these animals are more likely to be found.

If the fear is relatively mild, self-help measures such as guided visualization and purposeful breathing may soothe your stress responses. Talking to a supportive friend or relative can also be helpful. If the fear begins to limit the daily activities and feel of panic, then it is best to consult with a mental health professional (https://www.very-wellmind.com).

\section{Some of the useful methods}

Exposure-based therapy - (Singh and Singh, 2016) Cognitive therapy (CT) - (Specific phobia. http://www. med.upenn.edu).

Progressive desensitization (Specific phobia. http://www. med.upenn.edu).

Relaxation- (Specific phobia. http://www. med.upenn.edu).

Hypnosis (hypnotherapy)- (Natural treatment for phobia and anxiety. http://www.phobicss-ociety.org) Homeopathy- (http:// www.phobicssociety .org).

Herbal remedies- (Natural treatment for phobia and anxiety. http:// www.phobicssociety.org).

\section{CONCLUSION}

The present study made a comparison of the Zoophobia among $8^{\text {th }}$ to $10^{\text {th }}$ male and female students. Out of the total 1589 male students 327students have phobia. Similarly, in the case of female students, 379 students out of 1154 expressed the phobia. Highest percent of male (18.35) and female (34.81) students of Takkellapadu school expressed the phobia. State Government shall find the suitable mechanism to assess the specific phobias among the students and to treat the phobias. 


\section{ACKNOWLEDGEMENT}

Authors are thankful to Rotary club - Adharsh, Guntur Commissioner, GMC and the Authorities of Acharya Nagarjuna University for the financial assistance.

\section{REFERENCES}

[1]. Abbas Syeda Sarah and Kiran Sehrish (2015), People With Fear Of Height; Zoophobia, World Journal Of Pharmaceutical And Medical Research, 1(1), 52-5.

[2]. Carleton Nicholas R (2016) Fear of the unknown: One fear to rule them all?, Journal of Anxiety Disorders, 41, pp. 5-21.

[3]. Cornelius Randolph R. and James R. Averill (1983) Sex Differences in Fear of Spiders, Journal of Personality and Social Psychology, Vol. 45, No. 2, 377-383.

[4]. Curtis G C, Magee W J, Eaton WW, Wittchen H U and Kessler RC (1998), The British Journal of Psychiatry, 173:212-217.

[5]. de Oliveira-Souza R (2018), Phobia of the Supernatural: A Distinct but Poorly Recognized Specific Phobia With an Adverse Impact on Daily Living. Front. Psychiatry 9:590.

[6]. Garcia Rene (2017) Neurobiology of fear and specific phobias, Published by Cold Spring Harbor Laboratory Press, 24:462-471.

[7]. Katkin, E. S., \& Hoffman, L. S. Sex differences and self report of fear: A psycho physiological assessment. Journal of Abnormal Psychology, 1976, 85, 607-610.

[8]. Natural treatment for phobia and anxiety. Available at http:// www.phobicssociety .org.uk/natural treatment for phobia and anxiety/ Accessed on 24 December 2015.onal Journal of Basic \& C.

[9]. Naveed S, Sana A, Rehman H, Qamar F, Abbas SS, et al. (2015) Prevalence and Consequences of PHOBIAS, Survey Based Study in Karachi. J Bioequiv Availab 7: 140-143.

[10]. Ollendick Thomas H., Natoshia Raishevich, Thompson E. Davis III, Cristian Sirbu, LarsGöran Öst (2010) Phenomenology and Psychological Characteristics, Behavior Therapy 41, 133-141.

[11]. Pull Charles B. (2008) Recent trends in the study of specific phobias, Curr Opin Psychiatry 21:43-50.

[12]. Singh Jarnail, Singh Janardhan (2016) Treatment options for the specific phobias Int J Basic Clin Pharmacol, ;5(3):593-598.

[13]. Specific phobia. Available at http://www. med.upenn.edu/csta/phoias_treatment. html. Accessed on 26 December 2015.

[14]. Suárez Alcides Alvear, Shawn Disdier, Ricardo Cruz, Miguel Goenaga (2017) Virtual Reality Therapy Implementation for Zoophobia, Global Partnerships for Development and Engineering Education" 15th LACCEI International Multi-Conference for Engineering, Education, and Technology, http://dx.doi.org/10.18687/

LACCEI2017.1.1.448.

[15]. https://en.wikipedia.org/wiki/Entomophobia\#ci te_note-1

[16]. https://en.wikipedia.org/wiki/Zoophobia\#cite_ note-fdict-1

[17]. https://www.verywellmind.com/animalphobias-2671731

[18]. https://www.psychologytoday.com/us/blog/figh ting-fear/201305/strategy-dealing-animalphobias.

Cite this article as : Sankara Pitchaiah Podila, Nazia Sultana, "Zoophobia and Gender - A Case Study", International Journal of Scientific Research in Science and Technology (IJSRST), Online ISSN : 2395-602X, Print ISSN : 2395-6011, Volume 6 Issue 1, pp. 259-265, January-February 2019. Available at doi : https://doi.org/10.32628/IJSRST196137 Journal URL : http://ijsrst.com/IJSRST196137 